\title{
Investigation of the Genetic Basis of Tetracycline Resistance in Staphylococcus aureus from Pakistan
}

\author{
Farhat Ullah', Salman Akbar Malik², Jawad Ahmed ${ }^{3}$, Farman Ullah ${ }^{1}$, Syed \\ Majid Shah ${ }^{1}$, Muhammad Ayaz ${ }^{1}$, Sajid Hussain ${ }^{1}$ and Lubna Khatoon ${ }^{4}$ \\ ${ }^{1}$ Kohat University of Science and Technology, Kohat, ${ }^{2}$ Quaid-i-Azam University, Islamabad, ${ }^{3}$ Khyber Medical \\ University, Peshawar, ${ }^{4}$ University of Agriculture, Faisalabad, Pakistan
}

\begin{abstract}
Purpose: To determine the prevalence and genetic basis of tetracycline resistance in Staphylococcus aureus.

Methods: One hundred and thirty (130) clinical isolates of S. aureus were collected from Khyber Teaching Hospital, Peshawar, Pakistan. Susceptibility to antibiotics (doxycycline, tetracycline and minocycline) was determined by Kirby-Bauer disc diffusion method with minimum inhibitory concentration (MIC) evaluated on Muller-Hinton agar as described by the Clinical and Laboratory Standards Institute (CLSI). The tetracyclineresistant strains (TET-R) were screened by polymerase chain reaction (PCR) for the presence of four common tetracycline resistance determinants, viz, tet( $K)$, tet $(L)$, tet $(M)$ and tet $(O)$.

Results: Sixty (46.0\%) of these isolates were methicillin-resistant S. aureus (MRSA) while 70 (54.0\%) were methicillin-susceptible S. aureus (MSSA). Seventy four $(56.9 \%)$ strains were resistant to tetracycline (TET-R), 30 (23.1\%) to minocycline and 23 (17.7\%) to doxycycline. A majority of the MRSA were resistant to tetracyclines and all the MSSA were sensitive to doxycycline and minocycline. The tet $(K)$ gene was found in 58 isolates and tet $(L)$ in one isolate. No tet $(M)$ and tet $(O)$ were detected. Conclusion: This study indicates that resistance to tetracyclines is mainly by efflux pumps mediated by tet $(K)$ in S. aureus in northwestern Pakistan.
\end{abstract}

Keywords: Staphylococcus aureus, Antimicrobial susceptibility, Antibiotic resistance, Tetracycline, Pakistan 


\section{INTRODUCTION}

Tetracyclines are broad spectrum antibiotics used against a wide variety of bacterial infections, including both Gram-positive and Gram-negative. After their discovery in the 1940's, tetracyclines have continuously been used in both humans and animals with no major adverse effects. Tetracyclines inhibit bacterial ribosome from associating with the aminoacyl-tRNA and as a result, protein synthesis is inhibited. The discovery of tetracyclines sparked the development of many chemically altered antibiotics: including semisynthetic drugs such as minocycline and doxycycline [1].

A large number of tetracycline resistance genes have been identified. There are 38 acquired tetracycline resistance genes that are known and all use one of three strategies to render the bacteria resistant [2]. These include (1) efflux proteins, (2) ribosomal protection proteins and (3) enzymatic inactivation of tetracycline.

The majority of these genes $(60 \%)$ code for energy-dependent efflux pumps, and different bacterial genera tend to have the same efflux or ribosomal protection genes [3]. This indicates that tetracycline resistance genes can be transferred amongst the bacterial population. In fact, resistance to tetracycline in most bacteria is due to the acquisition of new genes; these genes tend to be associated with mobile elements such as transposons and plasmids [1]. Acne patients often require sequential treatment with tetracycline with several courses, which can last from three months to several years [4]. This long-term antibiotic treatment exerts a long selective pressure on both the targeted propionibacteria and the other microflora of the skin.

Tetacycline resistance genes: tetK, tetM, tetO and tet $L$ are four major genes associated with tetracycline resistance amongst Grampositive bacteria. The tetK and tet $\mathrm{L}$ genes code for efflux proteins; these are energy- dependent membrane-associated proteins which prevent tetracycline from accumulating within the cell [3]. The other two genes, tetM and tetO, code for ribosomal protection proteins, which reduce the affinity of tetracycline to the ribosome [5].

Surveillance for detection of various tet determinants has been carried out worldwide. In 2006, Jones et al found $74.0 \%$ tetK and $13.0 \%$ tetM in MRSA, and $73.8 \%$ tetK and $21.4 \%$ tetM in MSSA in a worldwide collection of $S$. aureus [6]. A study conducted by the SENTRY Antimicrobial Surveillance Programme between 1997 and 1999 found 57.0 and $10.0 \%$ resistance to tetracycline in MRSA and MSSA, respectively. They recorded high prevalence of tetM in MRSA $(76.0 \%)$ and of tetK in MSSA (96.0\%) [7].

Tetracyclines are extensively used in Pakistan for skin and throat infections. But little surveillance work has been done to assess the extent of resistance. The aim of this study was to determine the genetic basis of tetracycline resistance in $S$. aureus. This is the first report disclosing genetic basis of tetracycline resistance in $S$. aureus from Pakistan.

\section{EXPERIMENTAL}

\section{Bacterial strains}

Between April 2005 and May 2006, 130 nonduplicate, consecutive $S$. aureus isolates were collected from in- and out-patients at Khyber Teaching Hospital, a tertiary care hospital in Peshawar. In this study, $130 \mathrm{~S}$. aureus were obtained from various sources. There were 69 male and 61 female patients. A majority of the isolates were obtained from wound and burn/skin infections. Identification was carried out by Gram stain, catalase, coagulase and DNAse tests.

\section{Antimicrobial agents susceptibility testing}

Susceptibility to antimicrobial agents was determined by Kirby-Bauer disc diffusion and 
minimum inhibitory concentration (MIC) method on Muller-Hinton agar (Oxoid, England) as per Clinical and Laboratory Standards Institute (CLSI) guidelines [8]. The tetracycline antibiotics used against the collected strains were: doxycycline (DOX), tetracycline (TET), and minocycline (MN). E. coli NCTC 10418 was used as control for susceptibility testing.

\section{Bacterial DNA extraction}

Achromopeptidase method was used for DNA extraction. In this method, 50 ul of $\mathrm{NaCl}$ EDTA Tris (NET) buffer (1x TE buffer in PCR water plus $20 \mathrm{ul} 5 \mathrm{M} \mathrm{NaCl}$ ) was added to $10 \mathrm{ml}$ achromopeptidase solution in a small tube. Thereafter, 2 - 3 fresh colonies $(18-20 \mathrm{~h})$ of $S$. aureus were added and incubated for 15 $20 \mathrm{~min}$ at $50{ }^{\circ} \mathrm{C}$. After incubation, the extracted DNA was diluted 10 times in NET buffer for molecular work. The DNA was stored at $-4^{\circ} \mathrm{C}$ and used for up to one month.

\section{Confirmation of MRSA}

The phenotypically identified MRSA, using 30 $\mu \mathrm{g}$ cefoxitn disc, were genotypically confirmed by a duplex PCR targeting mecA gene responsible for methicillin resistance and a specific region of $16 \mathrm{~s}$ rDNA region of the $S$. aureus (nuc gene). The primers used are stated in Table 1.

\section{Determination of tetracycline resistance genes using PCR}

The presence of tetK, tetM, tet $\mathrm{L}$ and tetO genes responsible for tetracycline resistance was detected by PCR. The primer sequence, amplicon size and reference for the detection of each gene are given in Table 1.

\section{Agarose gel electrophoresis}

The amplified products were run on $1.5 \%$ agarose gel in Tris-Acetate EDTA (TAE) buffer for $45 \mathrm{~min}$. The ethidium bromide stained bands were examined under an ultraviolet transilluminator and photographed with a Kodak camera.

\section{Statistical analysis}

Statistical analysis was performed by Chisquare test (Minitab 15 software) and $p$ values of $\leq 0.05$ were considered significant.

Table 1: PCR primer sequences, amplicon size and PCR conditions

\begin{tabular}{|c|c|c|c|c|}
\hline $\begin{array}{l}\text { Gene } \\
\text { targeted }\end{array}$ & Primer sequence (5-3) & $\begin{array}{l}\text { Amplicon } \\
\text { size (bp) }\end{array}$ & Reference & PCR conditions \\
\hline mecA & $\begin{array}{l}\text { F-CTCAGGTACTGCTATCCACC } \\
\text { R-CACTTGGTATATCTTCACC } \\
\text { F-GCGATTGATGGTGATACGGTT }\end{array}$ & 449 & [9] & $\begin{array}{l}1 \text { cycle of } 95^{\circ} \text { for } 5 \mathrm{~min} \\
30 \text { cycles of } 95^{\circ} \mathrm{C} \text { for } 30 \mathrm{~s} \\
55^{\circ} \mathrm{C} \text { for } 30 \mathrm{se}\end{array}$ \\
\hline nuc & $\begin{array}{l}\text { R- } \\
\text { AGCCAAGCCTTGACGAACTAAAGC }\end{array}$ & 280 & [10] & $\begin{array}{r}72^{\circ} \mathrm{C} \text { for } 1 \mathrm{~min} \\
1 \text { cycle of } 72^{\circ} \mathrm{C} \text { for } 5 \mathrm{~min}\end{array}$ \\
\hline $\operatorname{tet}(\mathrm{K})$ & $\begin{array}{l}\text { F-GTAGCGACAATAGGTAATAGT } \\
\text { R-GTAGTGACAATAAACCTCCTA }\end{array}$ & 360 & [11] & 1 cycle of $95^{\circ}$ for $5 \mathrm{~min}$ \\
\hline $\operatorname{tet}(\mathrm{L})$ & $\begin{array}{l}\text { F-ATAAATTGTTTCGGGTCGGTAAT } \\
\text { R-AACCAGCCAACTAATGACAAGAT }\end{array}$ & 1077 & [12] & $\begin{array}{c}30 \text { cycles of } 95^{\circ} \mathrm{C} \text { for } 60 \mathrm{~s} \\
55^{\circ} \mathrm{C} \text { for } 60 \mathrm{~s}\end{array}$ \\
\hline $\operatorname{tet}(\mathrm{M})$ & $\begin{array}{l}\text { F-AGTTTTAGCTCATGTTGATG } \\
\text { R-TCCGACTATTTAGACGACGG }\end{array}$ & 1862 & [12] & $\begin{array}{c}72^{\circ} \mathrm{C} \text { for } 90 \mathrm{~s} \\
1 \text { cycle of } 72^{\circ} \mathrm{C} \text { for } 5 \mathrm{~min}\end{array}$ \\
\hline $\operatorname{tet}(\mathrm{O})$ & $\begin{array}{l}\text { F-AACTTAGGCATTCTGGCTCAC } \\
\text { R-TCCCACTGTTCCATATCGTCA }\end{array}$ & 515 & [13] & $\begin{array}{r}1 \text { cycle of } 94^{\circ} \text { for } 5 \mathrm{~min} \\
30 \text { cycles of } 94^{\circ} \mathrm{C} \text { for } 60 \mathrm{~s} \\
50^{\circ} \mathrm{C} \text { for } 60 \mathrm{~s} \mathrm{~s} \\
72^{\circ} \mathrm{C} \text { for } 90 \mathrm{~s} \\
1 \text { cycle of } 72^{\circ} \mathrm{C} \text { for } 5 \mathrm{~min}\end{array}$ \\
\hline
\end{tabular}




\section{RESULTS}

The age range of the patients was 3 months to 80 years with a mean of 28 years. There were $60(46.15 \%)$ isolates that were resistant to cefoxitin, i.e., were MRSA (methicillin resistant $S$. aureus). These MRSA strains were also confirmed by PCR. Among the tetracycline antibiotics tested, 98 (75.4\%) isolates were susceptible to minocycline, 79 $(60.8 \%)$ to doxycycline and $55(42.3 \%)$ to tetracycline. A significant difference was found in the susceptibilities of all the tetracyclines used $(p<0.05)$. Among MRSA, 30 strains $(50.0 \%)$ were resistant to minocycline, $23(38.3 \%)$ to doxycycline and $48(80.0 \%)$ to tetracycline. All the MSSA strains were sensitive to minocycline and doxycycline, while $26(37.1 \%)$ were resistant to tetracycline (Table 2).

On screening the 74 isolates resistant to tetracycline for the presence of tetK, tetO,
tetM and tet $\mathrm{L}$ genes, tetK gene was found in 58 isolates, made up of 34 among MRSA and 24 among MSSA. The electrophoretic gel photo for tetK is given in Figure 1. Only one tet $\mathrm{L}$ gene was found in MRSA. No tetM and tet $\mathrm{O}$ genes were found in these isolates.

All the tetK positive strains were highly resistant to tetracycline, $\mathrm{MIC}_{50}$ being $64 \mathrm{ml} / \mathrm{ml}$. The MIC distribution curve is shown in Figure 2. Among tetK positive S. aureus, 40 (67.8 $\%$ ) were susceptible to doxycycline and 19 $(32.2 \%)$ to minocycline.

\section{DISCUSSION}

This study was conducted to identify the molecular mechanisms of resistance against tetracycline by $S$. aureus in Pakistan. The results of tetracyclines susceptibility in this study are in agreement with those of others who observed 83 and $>50 \%$ resistance to tetracycline, respectively. [14,15].

Table 2: Susceptibility of the total isolated $S$. aureus and comparison of susceptibility between MRSA and MSSA to tetracyclines

\begin{tabular}{|c|c|c|c|c|c|}
\hline \multirow[b]{2}{*}{ Antiobiotic } & \multicolumn{5}{|c|}{ S. aureus $n=130$} \\
\hline & $\begin{array}{c}\text { Sensitive } \\
\mathbf{N}(\%)\end{array}$ & $\begin{array}{c}\text { Intermediate* } \\
\mathbf{N}(\%)\end{array}$ & $\begin{array}{l}\text { Resistant } \\
\text { N (\%) }\end{array}$ & $\begin{array}{l}\mathrm{MIC}_{50} \\
\text { (ug/ml) }\end{array}$ & $\begin{array}{l}\mathrm{MIC}_{90} \\
\text { (ug/ml) }\end{array}$ \\
\hline Minocycline & $98(75.38)$ & $02(01.54)$ & $30(23.08)$ & 2 & 64 \\
\hline Doxycycline & $79(60.77)$ & $28(21.54)$ & $23(17.69)$ & 4 & 16 \\
\hline \multirow[t]{2}{*}{ Tetracycline } & $55(42.31)$ & $1(0.77)$ & $74(56.92)$ & 16 & 64 \\
\hline & \multicolumn{5}{|c|}{ MRSA $n=60$} \\
\hline Minocycline & $28(46.67)$ & $2(00.33)$ & $30(50.00)$ & 8 & 64 \\
\hline Doxycycline & $18(30.00)$ & $19(31.67)$ & $23(38.33)$ & 8 & 16 \\
\hline \multirow[t]{2}{*}{ Tetracycline } & $12(20.00)$ & $0(0.00)$ & $48(80.00)$ & 64 & 128 \\
\hline & \multicolumn{5}{|c|}{ MSSA $n=70$} \\
\hline Minocycline & $70(100)$ & $0(0.00)$ & $0(0.00)$ & 2 & 4 \\
\hline Doxycycline & $61(87.14)$ & $9(12.86)$ & $0(0.00)$ & 0.25 & 1 \\
\hline Tetracycline & $43(61.43)$ & $1(1.43)$ & $26(37.14)$ & 1 & 16 \\
\hline
\end{tabular}




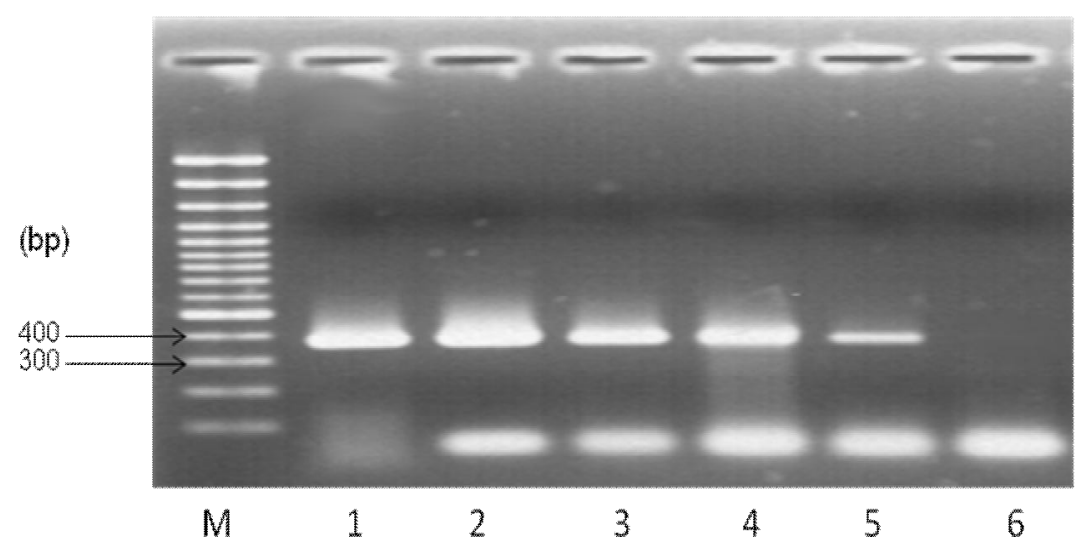

Fig 1. Agarose gel electrophoresis for tek gene. M :Molecular weight maker, Lane 1: Positive control, Lane 2: Isolate (1), Lane 3: Isolate (5), Lane 4: Isolate (8), Lane 5: Isolate (10), Lane 6: Negative control.

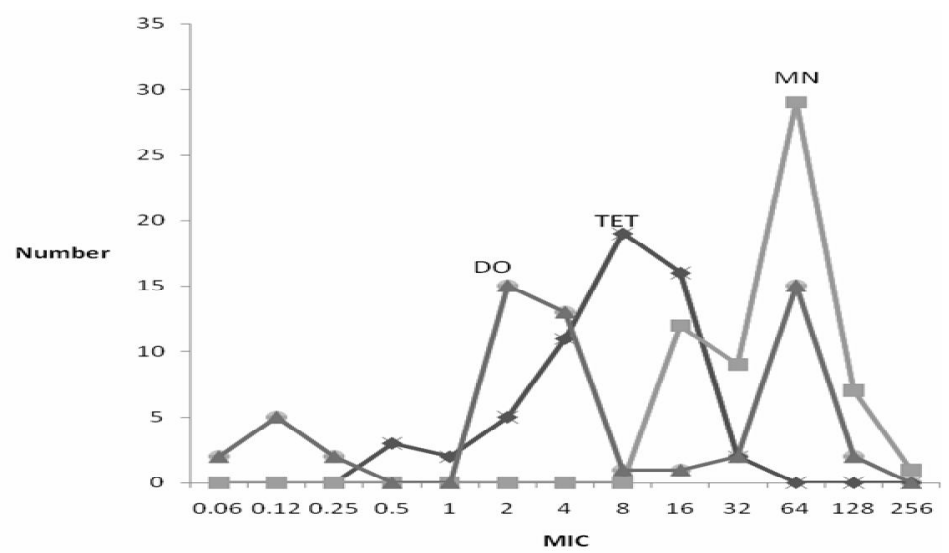

Fig. 2: MIC distribution of doxycycline (DO), tetracycline (TET) and minocycline (MN) among TET-R, tet $(\mathrm{K})$ gene positive $S$. aureus $(n=58)$

On screening the isolates for the presence of four commonly found tetracycline resistance genes, $58(78 \%)$ of the isolates were positive for tet $(\mathrm{K})$. The tet $(\mathrm{K})$ gene protects bacteria from tetracycline by a resistance mechanism known as tetracycline efflux. This mechanism prevents the accumulation of tetracycline within bacterial cells [1] by the synthesis of a cytoplasmic membrane protein which pumps tetracycline out of the cell at a quicker rate than it enters [3]. This may explain why tet $(\mathrm{K})$ gene does not impart resistance to minocycline.
Twenty four of the isolates had raised levels of resistance to minocycline, which was reflected in the $\mathrm{MIC}_{90}$ value of $64 \mathrm{ug} / \mathrm{ml}$. The raised level of minocycline resistance may be due to other tetracycline resistance genes, besides tet $(\mathrm{K})$ being present within the isolates that were not screened for.

Trzcinski et al, in a study conducted in Poland, found $66 \%$ tet $(\mathrm{K})$ in tetracyclineresistant MRSA [12]. Schmitz et al, in 1997 99, collected 400 MRSA and 200 MSSA from 25 university hospitals in Europe in the 
international SENTRY program. They detected tet(K) in $73 \%$ (292/400) MRSA and $96 \%(192 / 200)$ MSSA isolates [7]. Huys et al, in 2005, in a collection of $S$. aureus from poultry processing plants reported $58 \%$ $(22 / 38)$ tet $(\mathrm{K})$ in South Africa [16]. The level of tet $(\mathrm{K})$ genes present in the three studies provides evidence to suggest that the distribution of tet $(\mathrm{K})$ genes in $S$. aureus are wide spread. In addition to this, the frequency at which tet $(\mathrm{K})$ occurs signifies that in $S$. aureus, the main mechanism of resistance is through tetracycline efflux. This also suggests that when screening $S$. aureus for tetracycline resistance genes, tet(K) must always be screened for first.

No traces of tet $(\mathrm{O})$ were found in the current study and these findings correlate with those of Bismuth et al. This suggests that this gene is rare in $S$. aureus, unlike tet(K). In addition, there is very little evidence to indicate the occurrence of tet(L) in Staphylococci species, as indicated by both Bismuth et al and Trzcinski et al. As a result, this study as qell as previous studies indicate that tet $(\mathrm{K})$ is widely distributed, and therefore, is more likely to be found in $S$. aureus.

\section{CONCLUSION}

The findings of this study indicate the mechanism of resistance to tetracyclines in $S$. aureus isolates from Pakistan could be through the production of efflux pumps, encoded mostly by tet(K).

\section{ACKNOWLEDGEMENT}

Higher Education Commission of Pakistan is acknowledged for providing funds for this project.

\section{REFERENCES}

1. Chopra I, Roberts M. Tetracycline antibiotics: mode of action, applications, molecular biology, and epidemiology of bacterial resistance. Microbiol Mol Biol Rev 2001; 65(2): 232-260

2. Roberts MC. Update on acquired tetracycline resistance genes. FEMS Microbiol Lett 2005; 245(2): 195-203.
3. Speer BS, Shoemaker NB, Salyers AA. Bacterial resistance to tetracycline: mechanisms, transfer, and clinical significance. Clin Microbiol Rev 1992; 5(4): 387-399.

4. Coates $P$, Vyakrnam S, Eady EA, Jones CE, Cove $\mathrm{JH}$, Cunliffe WJ. Prevalence of antibioticresistant propionibacteria on the skin of acne patients: 10-year surveillance data and snapshot distribution study. $\mathrm{Br} J$ Dermatol 2002; 146(5): 840-848.

5. Bismuth $R$, Zilhao $R$, Sakamoto $H$, Guesdon $J$ L, Courvalin $P$. Gene heterogeneity for tetracycline resistance in Staphylococcus spp. Antimicrob Agents Chemother 1990; 34(8): 1611-1614.

6. Jones $\mathrm{CH}$, Tuckman $M$, Howe $A Y$, Orlowski $M$, Mullen S, Chan K, Bradford PA. Diagnostic $P C R$ analysis of the occurrence of methicillin and tetracycline resistance genes among Staphylococcus aureus isolates from phase 3 clinical trials of tigecycline for complicated skin and skin structure infections. Antimicrob Agents Chemother 2006; 50(2): 505-510.

7. Schmitz FJ, Krey A, Sadurski R, Verhoef J, Milatovic $D$, Fluit AC. Resistance to tetracycline and distribution of tetracycline resistance genes in European Staphylococcus aureus isolates. J Antimicrob Chemother 2001; 47(2): 239-240.

8. CLSI. Clinical and Laboratory Standards Institute (CLSI): Performance Standard for Antimicrobial Susceptibility Testing. 16th Informational supplement. CLSI document 2006; M100-S16. Wayne, PA 2006.

9. Bignardi GE, Woodford N, Chapman A, Johnson $A P$, Speller DC. Detection of the mec-A gene and phenotypic detection of resistance in Staphylococcus aureus isolates with borderline or low-level methicillin resistance. J Antimicrob Chemother 1996; 37(1): 53-63.

10. Brakstad OG, Aasbakk K, Maeland JA. Detection of Staphylococcus aureus by polymerase chain reaction amplification of the nuc gene. J Clin Microbiol 1992; 30(7): 1654-1660.

11. Strommenger $B$, Kettlitz $C$, Werner $G$, Witte $W$. Multiplex PCR assay for simultaneous detection of nine clinically relevant antibiotic resistance genes in Staphylococcus aureus. $J$ Clin Microbiol 2003; 41(9): 4089-4094.

12. Trzcinski K, Cooper BS, Hryniewicz W,Dowson CG. Expression of resistance to tetracyclines in strains of methicillin-resistant Staphylococcus aureus. J Antimicrob Chemother 2000; 45(6): 763-770.

13. Ng LK, Martin I, Alfa M, Mulvey M. Multiplex PCR for the detection of tetracycline resistant genes. Mol Cell Probes 2001; 15(4): 209-215.

14. Sekiguchi J, Fujino T, Saruta K, Kawano F, Takami $J$, Miyazaki $H$, Kuratsuji $T$, Yoshikura $H$, Kirikae T. Spread of erythromycin-, tetracycline-, and aminoglycoside-resistant genes in methicillin-resistant Staphylococcus aureus clinical isolates in a Kumamoto 
Ullah et al

Hospital. Jpn J Infect Dis 2003; 56(3): 133137.

15. Saderi H, Owlia P, Habibi M. Mupirocin resistance among Iranian isolates of Staphylococcus aureus. Med Sci Monit 2008; 14(10): BR210213.
16. Huys G, D'Haene $K$, Van Eldere J, von Holy $A$, Swings J. Molecular diversity and characterization of tetracycline-resistant Staphylococcus aureus isolates from a poultry processing plant. Appl Environ Microbiol 2005; 71(1): 574-579. 